\title{
MONOXYL Z DOBY LATÉNSKEJ ZO ŠAMORÍNA
}

\section{Peter Barta* - Ján Sládek** - Mária Hajnalová*** - Ivan Nagy****}

\author{
* Katedra archeológie, Filozofická fakulta, Univerzita Komenského v Bratislave, Gondova 2, 81102 Bratislava, peter.barta@uniba.sk \\ ** Geografický ústav SAV, Štefánikeova 49, 81473 Bratislava \\ *** Katedra archeológie, Filozofická fakulta, Univerzita Konštantína Filozofa v Nitre, Hodžova 1, 94974 Nitra \\ ****Žitnoostrovské múzeum v Dunajskej Strede, Múzejná 2, 92901 Dunajská Streda
}

\begin{abstract}
A La Tène period logboat from Šamorín. In the article we present preliminary results of research of a logboat housed in the Žitný Ostrov Museum in Dunajská Streda. According to our research the boat comes from the $3^{\text {rd }}$ century or later part of the last third of $1^{\text {st }}$ millennium cal BCE. It is the earliest chronometrically dated vessel countrywide and the second specimen of Late Iron Age logboats known from Slovak and Czech Republics.
\end{abstract}

Keywords: logboat, La Téne period, SW Slovakia, ${ }^{14} \mathrm{C}$ dating, digitisation

\begin{abstract}
Abstrakt: Článok predstavuje prvé výsledky prebiehajúceho výskumu a dokumentácie monoxylu uloženého v Žitnoostrovskom múzeu v Dunajskej Strede. Náš chronometrický výskum dokazuje, že monoxyl pochádza z 3. storočia alebo neskoršej časti poslednej tretiny 1. tisícročia pred n. l. Predstavuje tak najstarší známy archeologický nález plavidla u nás a druhý exemplár monoxylu z doby laténskej na území Slovenskej a Českej republiky.
\end{abstract}

Kl'účové slová: monoxyl, doba laténska, JZ Slovensko, ${ }^{14} \mathrm{C}$ datovanie, digitalizácia

https://doi.org/10.46283/musarch.2020.2.04

\section{1. Úvod}

Monoxyly, člny vyrobené z jedného kusa kmeňa, patria k najstarším typom plavidiel vôbec. Ich archeologické nálezy sú na území Slovenska vzácne, za posledných 50 rokov poznáme z literatúry dva. Ten známejší je čln z Krásnej, dnes mestskej časti Košíc (v minulosti Krásna nad Hornádom) publikovaný v ročenke AVANS (Čaplovič - Gašaj - Olexa 1978).

Tým menej známym monoxylom je exemplár zo Šamorína. Do literatúry ho uviedol historik a pedagóg László Kovács (Kovács 1982). Doteraz bolo známe, že sa monoxyl našiel „na štrkovisku pri Šamoríne“ (Kovács 1982). V rámci prezentovaného výskumu sme autora oslovili s prosbou o spresnenie miesta nálezu, ktoré lokalizoval do chotárnej časti Négyesek (L. Kovács, ústna informácia 2020).

Šamorín (okr. Dunajská Streda, Trnavský samosprávny kraj) leží v Podunajskej rovine, na Žitnom ostrove, na l'avom brehu Dunaja zhruba $25 \mathrm{~km}$ juhovýchodne od Bratislavy. Pre geomorfologický vývoj tohto územia v holocéne bola najvýznamnejšia fluviálna činnost’ Dunaja a jeho meandrov, s čím súvisí terajší geologický podklad tvorený nivnými hlinami a fluviálnymi sedimentmi rôznej zrnitosti (Geologická mapa Slovenska).

Skúmaný monoxyl našiel bagrista Gejza Horváth pri t’ažbe štrku v híbke 3,5 - $4 \mathrm{~m}$ v auguste roku 1982 (Kovács 1982, L. Kovács ústna informácia 2020). Pri vyzdvihovaní sa čln rozlomil na dva kusy, ktoré previezli do Žitnoostrovského múzea v Dunajskej Strede (Kovács 1982). Jedinou indíciou pre datovanie monoxylu bol predmet, ktorý sa mal nachádzat' vo vnútri člna a je opísaný ako vel’mi poškodená prachovnica z 2. pol. 19. stor. (Kovács 1982).

Ciel’om nášho článku je zverejnit' nové dôležité zistenia týkajúce sa najmä datovania monoxylu, ktoré predstavujú prvé výsledky prebiehajúceho výskumu tohto artefaktu. Výskum bol vyvolaný záujmom etnológa a súčasného 


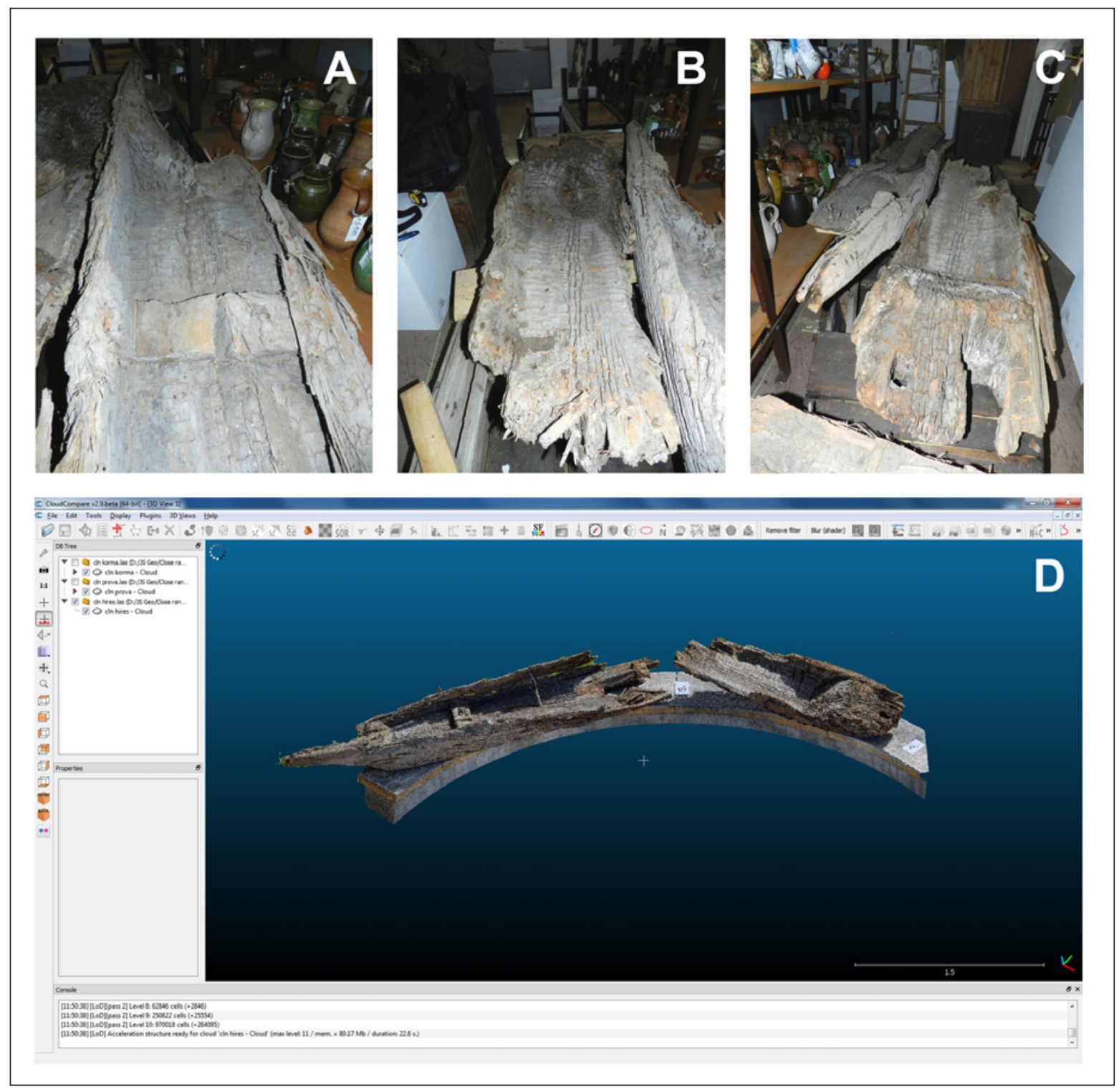

Obr. 1. Uloženie člna zo Šamorína v depozitári Žitnoostrovského múzea v Dunajskej Strede a jeho digitalizácia, stav v rokoch 2016 a 2018. A - predná čast' trupu s nízkym priečnym rebrom, kolabovanou stenou pravoboku a čiastočne zachovanou provou v pozadí vl'avo; B - vl’avo: zadná čast' trupu člna s kormou, vpravo: prova a predná čast' trupu; C - vl’avo: zachovaná čast' provy, vpravo: korma s dvoma otvormi a vyseknutou jamkou; D - pracovná snímka z digitalizácie oboch častí člna v prostredí CloudCompare (kolorované mračno bodov). Kolabovaná stena pravoboku prednej časti trupu bola pred dokumentovaním podopretá, aby bola čo najlepšie viditel'ná miera zachovania artefaktu. Prednú čast' člna tvorí čast' provy, steny a dno trupu člna, dobre je viditel'né nízke priečne rebro. Fragment zadnej časti tvorí dno a čiastočne zachované bočné steny trupu, korma s dvoma otvormi je zachovaná relatívne dobre (foto: P. Barta, screenshot: J. Sládek).

Fig. 1. Logboat from Šamorín in the storage of Žitný Ostrov Museum in Dunajská Streda and screenshot from digitisation, 2016 and 2018. A - front part of the boat with a low transverse ridge, collapsed right side of the hull and partly preserved bow visible on the left back; B - on the left: back part of the boat with stern, on the right: front part with bow; C - on the left: preserved part of bow, on the right: stern with two openings; D - a screenshot from digitisation in CloudCompare environment (coloured point cloud) showing front and back part of the logboat. Collapsed right side of the hull was supported in order to document the extent of preserved hull. The front part of the boat has preserved left portion of the bow, sides and floor of the hull with well visible transverse ridge. The back part of the boat has partly retained sides and floor and well preserved stern with two openings (photograph: P. Barta, screenshot: J. Sládek). 
riaditel’a múzea Ivana Nagya, ktorý oslovil prvého autora príspevku. V doterajšej práci sme sa sústredili predovšetkým na identifikáciu dreva, z ktorého monoxyl vyrobili a na výskum veku člna, prebehlo tiež fotografické dokumentovanie s ciel'om vytvorit' digitálny 3D model artefaktu. V súčasnosti na člne prebiehajú konzervátorské a reštaurátorské práce (Mgr. František Šmigrovský).

\section{Materiál a metódy: dokumentácia člna, determinácia dreviny a chronometrický výskum}

V Žitnoostrovskom múzeu sú vol'ne uložené dva vel'ké fragmenty, ktoré predstavujú prednú a zadnú čast' plavidla (obr. 1). Zachovalo sa tiež niekol'ko menších a drobných fragmentov stien, ktoré sa v priebehu uskladnenia z hmoty člna uvol'nili. Predná čast' člna má maximálnu dížku $332 \mathrm{~cm}$, zadná čast' $187 \mathrm{~cm}$, vonkajšia šírka člna je $59-65 \mathrm{~cm}$, hrúbka bočných stien trupu je $2-7 \mathrm{~cm}$, ich v súčasnosti zachovaná výška je maximálne $28 \mathrm{~cm}$. Monoxyl má neúplne zachovanú l’avú čast' provy, korma je zachovaná úplne a je slabo zaoblená. Na korme sa nachádza hlboký výrez (obr. 1C, na korme vpravo), ktorý mohol slúžit' na veslovanie (tzv. veslovanie vrtom, Kovács 1982), možno pôvodne nešlo o výrez, ale o otvor s vel'kost’ou približne 15 x 14 cm (F. Šmigrovský, osobná komunikácia 2020). Na korme sa nachádza aj menšia vyseknutá pravouhlá jamka s rozmermi 4 × $3 \mathrm{~cm}$ (obr. 1C, na korme v strede) a d'alší vysekaný otvor s rozmermi 6 x 5,5 cm (F. Šmigrovský, osobná komunikácia 2020), ktorým je korma perforovaná (obr. 1C, na korme vl'avo). V prednej časti trupu je z masívu kmeňa vytesané nízke priečne rebro, steny a dno trupu sú rovné. Drevo je poškodené početnými prasklinami, ktoré vznikli v priebehu postexkavačného vysychania a ako reakcia už vyschnutého materiálu na zmeny vlhkosti a teploty okolitého vzduchu. Kvôli prasklinám a deformitám povrchu nie je dnes spôsob opracovania povrchu zretel'ný.

Pre vytvorenie 3D modelu monoxylu pred jeho konzerváciou a reštaurovaním boli použité metódy blízkej fotogrametrie. Vzhl’adom na stav a technické možnosti bol čln snímkovaný v priestoroch Žitnoostrovského múzea, ktoré nie je špeciálne vybavené na tento typ dokumentácie. Pre snímkovanie bol použitý fotoaparát NikonD610 s objektívom $19 \mathrm{~mm}$. Fotografie boli spracované v prostredí RealityCapture. Do výpočtu bolo zahrnutých celkovo 374 fotografií.

Vzorka dreva pre mikroskopicko-anatomickú determináciu bola odobratá zo zadnej časti trupu. Anatomické štruktúry na plochách v transverzálnej, radiálnej a tangenciálnej rovine, ktoré sme získali odlomením, sme bez d’alšej preparácie pozorovali v odrazenom svetle pod mikroskopom Zeiss AxioLab A1 pri maximálnom zväčšení 200x. Pre zistenie taxónu sme použili štandardný atlas (Schweingruber 1990), porovnávaciu zbierku driev tretej autorky (MH) a internetový kl'úč na identifikáciu semenných rastlín (Heiss 2009).

Pri chronometrickom výskume člna sme uprednostnili rádiouhlíkové datovanie pred dendrochronologickou analýzou. Urobili sme tak kvôli neznámej proveniencii monoxylu (vzhl’adom na prítomnost' Dunaja) a s tým súvisiacou absenciou alebo nedostupnost'ou vhodných štandardných chronológií. Pred konzervovaním sme z dreva člna odobrali tri ${ }^{14} \mathrm{C}$ vzorky s kontrolovanou polohou v rámci kmeňa stromu (A, B, C, obr. 2). Každá zo vzoriek obsahovala 7 ročných kruhov. Atmosférická koncentrácia rádiouhlíka totiž spravidla

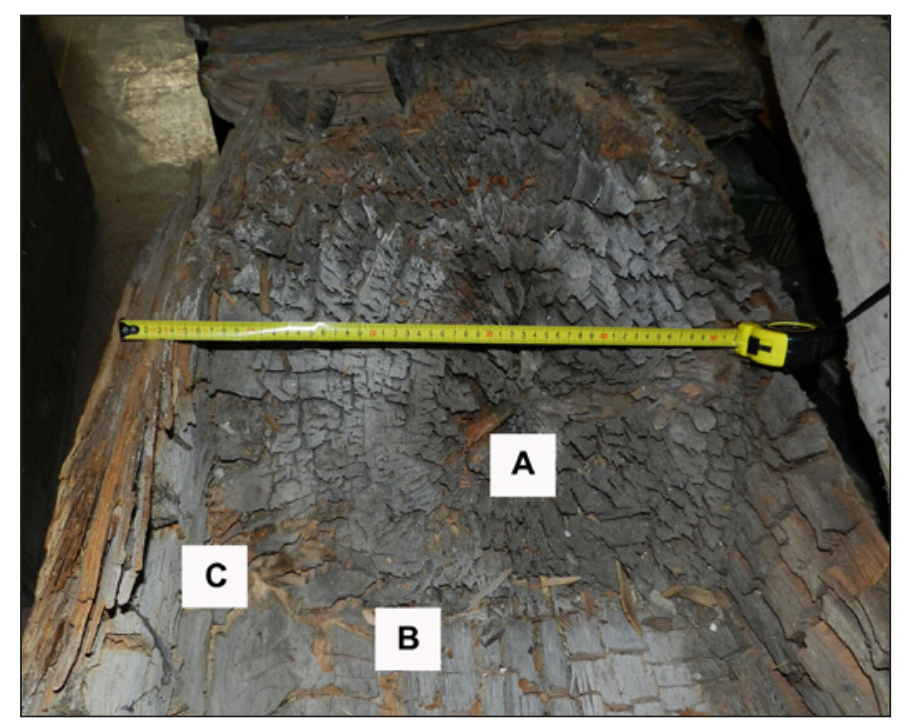

Obr. 2. Monoxyl zo Šamorína. Priečne zošikmenie vymedzujúce zadnú čast' vnútra člna s označenými miestami odberu

${ }^{14} \mathrm{C}$ vzoriek (foto: P. Barta).

Fig. 2. Logboat from Šamorín. Transversal sloping between stern and inside of the hull with location of ${ }^{14} \mathrm{C}$ samples (photograph: P. Barta). 
neumožňuje na základe jednej ${ }^{14} \mathrm{C}$ vzorky získat' výsledok s jemným chronologickým rozlíšením. Napríklad, ak by sme jednu vzorku pozostávajúcu zo siedmych ročných kruhov, ktoré narástli v 19. storočí n. 1., datovali rádiouhlíkovou metódou, výsledok datovania by zahŕňal viaceré intervaly niekde v rozpätí od neskorého 17 . do 20. storočia n. 1 . (cf. IntCal20, Reimer et al. 2020).

Odber ${ }^{14} \mathrm{C}$ vzoriek sme uskutočnili skalpelom. Od odberu jadrovým vrtákom sme ustúpili pre mnohopočetné praskliny v materiáli a preto, aby sme sa vyhli d’alšiemu invazívnemu narušeniu zbierkového predmetu. Vhodným miestom pre odber skalpelom bolo priečne zošikmenie z kormy smerom do vnútra trupu (obr. 2). Po jemnej preparácii povrchu skalpelom tu bolo možné kontrolovat’ vzájomné rozstupy medzi vzorkami a zistit' kol'ko ročných kruhov jednotlivé ${ }^{14} \mathrm{C}$ vzorky oddeluje.

Pre meranie konvenčného rádiouhlíkového veku sme vybrali dve nezávislé laboratóriá, v ktorých sa vzorky B a $C$ analyzovali urýchlovačovou hmotnostnou spektrometriou (AMS). Vzorku B sme nechali analyzovat'v rádiouhlíkovom laboratóriu Beta Analytic (Miami, USA) ako drevnú hmotu vcelku. Tu sa pred grafitizáciou vzorka chemicky pripravovala preplachmi $\mathrm{HCl}-\mathrm{NaOH}-\mathrm{HCl}$. Vzorka bola tiež charakterizovaná izotopovou pomerovou hmotnostnou spektrometriou (tab. 1). Vzorku C sme zaslali do laboratória CIRCE (Caserta, Taliansko; Terrasi et al. 2008) s požiadavkou homogenizácie všetkých siedmych ročných kruhov a extrakcie $\alpha$-celulózy. Vzorka sa chemicky pripravovala a grafitizovala v súlade s vnútornými laboratórnymi štandardmi (Passariello et al. 2007).

Dobu výroby monoxylu sme zist’ovali chronologickým modelovaním. Kalibráciu nameraných hodnôt konvenčného rádiouhlíkového veku sme urobili v prostredí OxCal4 (Bronk Ramsey 2009) s databázou IntCal20 (Reimer et al. 2020) s pät'ročným rozlíšením.

\section{Výsledky a diskusia: typ člna, stav digitalizácie artefaktu, drevo a vek člna}

Základná morfometrická charakteristika radí skúmaný monoxyl medzi stredne vel'ké plavidlá z východnej časti strednej Európy (cf. Rogers 2011). Z typologického hladiska predstavuje náš monoxyl typ člnu s jedným alebo viacerými priečnymi rebrami, čím je blízky moravským nálezom (Rogers 2011; Peška 2000, 2020).

Výstupom digitalizácie monoxylu je kolorované mračno bodov (obr.1D), mesh a textúrovaný mesh. Na hotovom digitálnom 3D modeli je možné realizovat' merania, rezy a prehliadanie monoxylu bez potreby fyzickej manipulácie s artefaktom.

\begin{tabular}{|c|c|c|c|c|c|c|c|}
\hline Vzorka & $\begin{array}{l}\text { Počet } \\
\text { ročných } \\
\text { kruhov }\end{array}$ & $\begin{array}{c}\text { Materiál } \\
\text { vzorky }\end{array}$ & $\begin{array}{c}\text { Laboratórny } \\
\text { kód }\end{array}$ & $\begin{array}{c}\text { Konvenčný } \\
{ }^{14} \text { C vek } \\
\text { BP } \\
\end{array}$ & $\begin{array}{c}\text { Kalibrovaný vek } \\
\text { cal BCE } \\
\text { nemodelovaný }\end{array}$ & $\begin{array}{c}\text { Kalibrovaný vek } \\
\text { cal BCE } \\
\text { modelovaný }\end{array}$ & $\begin{array}{c}\delta^{13} \mathrm{C}_{\text {IRMS }} \\
(\% 0)\end{array}$ \\
\hline DUS_B & 7 & drevo & Beta-456175 & $2337 \pm 32$ & $\begin{array}{c}68,3 \% \text { pravdepodobnost' } \\
451-446(2,1 \%) \\
416-379(66,2 \%) \\
95,4 \% \text { pravdepodobnost' } \\
516-361(93,7 \%) \\
274-264(1,0 \%) \\
242-235(0,7 \%)\end{array}$ & $\begin{array}{c}68,3 \% \text { pravdepodobnost' } \\
446-442(3,1 \%) \\
417-387(65,2 \%) \\
95,4 \% \text { pravdepodobnost' } \\
459-377(92,2 \%) \\
278-262(3,2 \%)\end{array}$ & -25.6 \\
\hline DUS_C & 7 & $\alpha$-celulóza & DSH-8092_CE & $2160 \pm 30$ & $\begin{array}{c}68,3 \% \text { pravdepodobnost' } \\
350-305(28,7 \%) \\
208-151(37,2 \%) \\
130-122(2,4 \%) \\
95,4 \% \text { pravdepodobnost' } \\
356-279(36,4 \%) \\
257-248(1 \%) \\
233-97(56,1 \%) \\
72-57(2.0 \%)\end{array}$ & $\begin{array}{c}68,3 \% \text { pravdepodobnost' } \\
320-285(68,3 \%) \\
95,4 \% \text { pravdepodobnost' } \\
356-276(92,3 \%) \\
180-161(3,2 \%)\end{array}$ & nemerané \\
\hline
\end{tabular}

Tab. 1. Monoxyl zo Šamorína. Konvenčný rádiouhlíkový vek a kalibrovaný vek vzoriek B a C.

Tab. 1. Logboat from Šamorín. Conventional radiocarbon ages and calibrated dates of samples B and C. 
Mikroskopicko-anatomický výskum dreva v transverzálnom reze ukázal vysušením výrazne deformované štruktúry nezuhol'nateného, nemineralizovaného, pôvodne vodou konzervovaného, typického pletiva ihličnatej dreviny výlučne s prítomnost'ou cievic. Napriek silnej deformácii bolo na ploche 2 x $1 \mathrm{~cm}$ jasne viditel'ných 18 ročných prírastkov. Zaznamenaný bol jeden živicový kanálik, v prípade ktorého nejde o traumatický kanálik ako vyplýva z nálezu na radiálnom reze. Na radiálnom reze sa vyskytol typický nález indikujúci borovicu (pinoid pits), ktorý vylučuje, že by išlo o iné ako borovicové drevo (Schweingruber 1990). Na nefarbenej vzorke nebolo možné zistit' či transverzálne tracheidy majú steny zúbkované (borovica lesná) alebo hladké (borovica limba). Čo sa týka použitia borovicového dreva na výrobu monoxylov, v Česku nie je známy ani jeden borovicový monoxyl (Rogers 2011, tab. 2), v Pol’sku sa vyskytujú borovicové exempláre datované do stredoveku a novoveku (Pazdur et al. 2001, tab. 1) a v severnej a západnej Európe borovicu používali pre výrobu člnov už v mezolite a neolite (Lanting 1998, 635, 636, 639).

Pri chronometrickom výskume je potrebné oddelit' dobu, ktorú chceme datovat' od doby, ktorú chronometrická vzorka datuje priamo (archeologická udalost' a udalost'; cf. Barta 2008). Dobu výroby člnu (archeologická udalost') môžeme stotožnit' s dobou výrubu stromu. Dátum výrubu je možné zistit' na základe datovania podkôrového letokruhu, ktorý sa však pre otesanie kmeňa na člne nenachádza. Môžeme však zistit' dobu rastu posledného na monoxyle zachovaného ročného kruhu, ktorá predstavuje terminus post quem pre výrobu člnu.

Každá z troch odobratých ${ }^{14} \mathrm{C}$ vzoriek (A, B, C), obsahuje sedem ročných kruhov (obr. 2). Zatial’ sme analyzovali vzorky B a C. Medzi strednými ročnými kruhmi týchto vzoriek rástlo $101 \pm 5$ ročných kruhov. Neistota \pm 5 je realistickým odhadom chyby, ktorá súvisí s našim rozhodnutím invazívnejšie nepreparovat' povrch člnu a preto na miestach, kde boli ročné kruhy úzke, nebol ich presný počet viditel'ný. V tejto neistote je tiež zohl'adnená skutočnost', že v laboratóriu Beta analyzovali iba čast’ z ročných kruhov, ktoré zaslaná vzorka obsahovala.

Ked’že sme monoxyl nevzorkovali invazívne (jadrovým vrtákom), presný počet ročných kruhov medzi vzorkou C (obr. 2) a posledným na vonkajšom obvode člna zachovaným ročným kruhom nepoznáme. Na základe pozorovatel'ných ročných kruhov na artefakte bolo však možné realisticky odhadnút', že posledný ročný kruh v susedstve miesta odberu vzorky $\mathrm{C}$ je od nej vzdialený $9 \pm 5$ ročných kruhov.

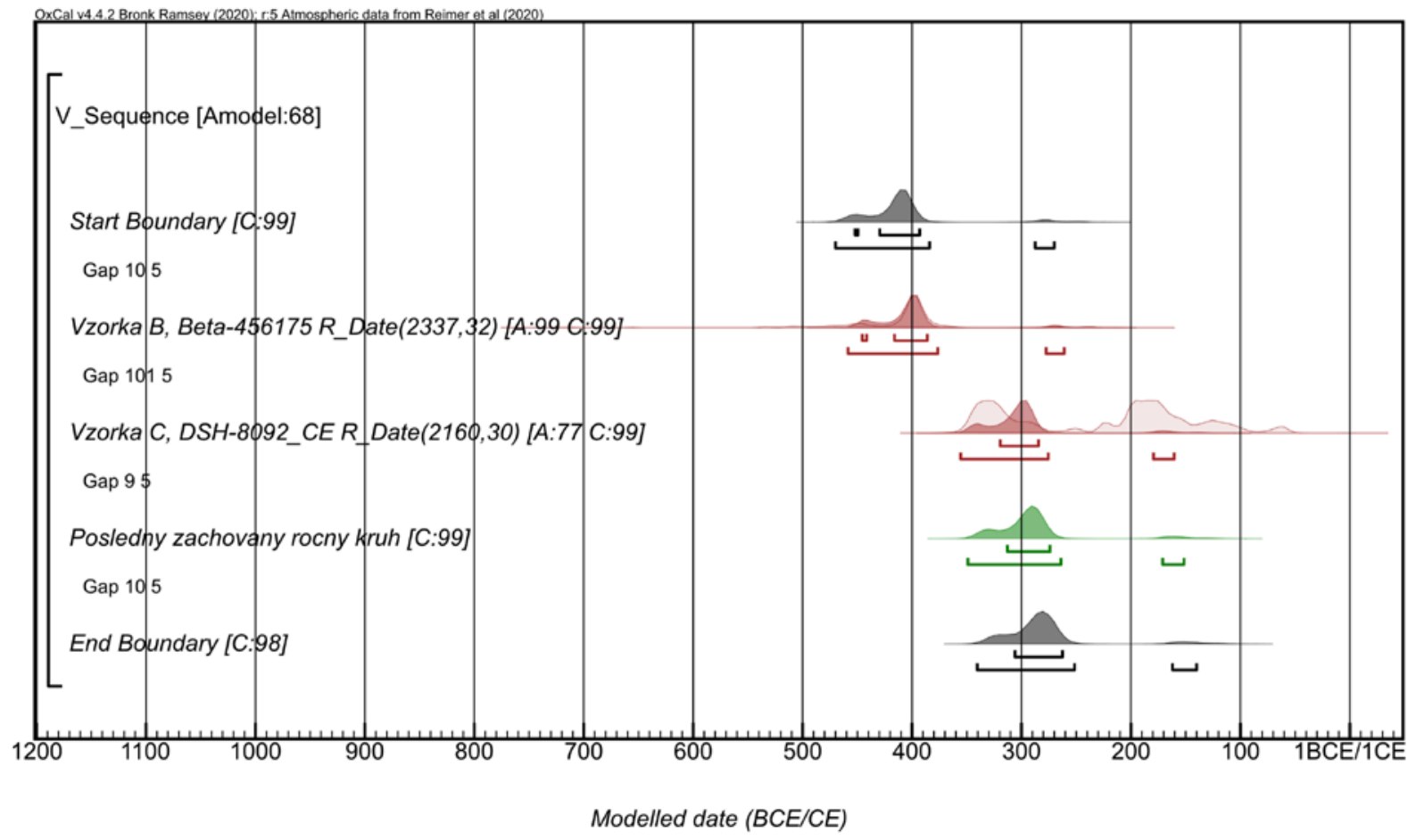

Obr. 3. Chronologický model pre datovanie posledného zachovaného ročného kruhu na monoxyle zo Šamorína (68,3\% a 95,4\% pravdepodobnost').

Fig. 3. Chronological model for dating of last retained year-ring on the logboat from Šamorín (68.3 and $95.4 \%$ probability). 
Chronologický model (obr. 3) sme vytvorili z dvoch hodnôt konvenčného rádiouhlíkového veku pre vzorky B a C a z informácií o počte kruhov medzi vzorkami B a C a medzi vzorkou $\mathrm{C}$ a posledným zachovaným ročným kruhom na vonkajšom obvode člna. Na základe modelu je posledný ročný kruh na vonkajšom obvode so 68,3\% pravdepodobnost'ou datovaný do intervalu $314-275$ cal BCE (obr. 3). S pravdepodobnost'ou 95,4 \% je datovaný do intervalu 350 - 265 cal BCE (92,5\%) alebo do intervalu 172 - 152 cal BCE; interval 172 - 152 cal BCE považujeme za artefakt kalibračnej krivky (obr. 3). Posledný ročný kruh zachovaný na vonkajšom obvode monoxylu teda narástol v intervale 350 - 265 pred n. 1. (92,5\% pravdepodobnost'), ktorý predstavuje pre výrobu monoxylu terminus post quem.

Vzhl’adom na to, že pri výrobe monoxylu nepredpokladáme dlhodobé skladovanie materiálu a extrémne vel'ký úbytok dreva pri otesávaní, ale skôr výber vhodného kmeňa s najmenším možným budúcim opracovaním, nepokladáme za realistické klást' dátum výroby člna d’aleko za mladšiu hranicu intervalu 350 - 265 cal BCE. Výrobu monoxylu zo Šamorína preto datujeme do 3. stor. pred n. 1. Ak však došlo pri výrobe člna k vel'kého úbytku hmoty, alebo by bolo otesané vel'ké množstvo úzkych okrajových ročných kruhov, bolo by datovanie monoxylu posunuté smerom do priebehu poslednej tretiny 1. tisícročia pred n. 1 .

Nášmu člnu je chronologicky najbližší 10,5 m dlhý dubový monoxyl s priečnymi rebrami z Mohelnice, ktorého výroba je dendrochronologicky datovaná po roku 281 pred n. 1. (Peška 2020, 100; Rogers 2011, tab. 1).

\section{Záver a perspektívy}

Príspevok predstavuje predbežné výsledky prvého komplexného výskumu monoxylu zo Šamorína uloženého v Žitnoostrovskom múzeu v Dunajskej Strede. Výskum dosial’ priniesol spresnenie miesta nálezu, zistenie veku plavidla a určenie druhu použitého dreva. Čln bol nájdený v roku 1982 počas t’ažby štrku v chotárnej časti Négyesek, na mieste, ktoré je dnes pod hladinou vodného diela Gabčíkovo (L. Kovács, ústna informácia 2020, cf. Kovács 1982). Podl’a mikroskopicko-anatomickej analýzy bol vyrobený z borovicového dreva. Posledný na obvode monoxylu zachovaný ročný kruh narástol medzi rokmi 350 a 265 cal BCE (92,5\% pravdepodobnost'), čo výrobu člnu datuje do 3. stor. pred n. 1., resp. do priebehu poslednej tretiny 1. tisícročia pred n. 1. Čln bol teda vyrobený na sklonku staršej (LT B) alebo v priebehu strednej doby laténskej (LT C).

Monoxyl zo Šamorína je v súčasnosti najstarším chronometricky datovaným nálezom plavidla z územia Slovenska. V rámci publikovaných datovaných monoxylov z Českej (pät’ člnov; Rogers 2011, tab. 1) a Slovenskej republiky ide popri člne z Mohelnice (Peška 2000; 2020; Rogers 2011) o druhý exemplár z doby laténskej. Mohelnický a šamorínsky monoxyl predstavujú dva priame doklady rozmanitosti stredoeurópskych plavidiel mladšej doby železnej. Morfometrická rozmanitost' monoxylov môže súvisiet's rôznymi faktormi, napr. rôznorodou funkciou, s požiadavkami na plavbu na konkrétnom vodnom toku, s regionálnymi výrobnými tradíciami alebo preferenciami individuálnych výrobcov (cf. Lanting 1998; Pazdur et al. 2001; Martinelli - Cherkinsky 2009).

Laténsky monoxyl zo Šamorína obohacuje skromný nálezový fond z tohto obdobia na Žitnom ostrove (cf. Březinová 2006). V súvislosti s pokračovaním výskumu člna plánujeme venovat' pozornost' jeho nálezovým okolnostiam a prípadným súvislostiam miesta nálezu s laténskymi lokalitami na l'avobreží Dunaja (napr. Šamorín, Kvetoslavov; Brezinová 2006, mapa 1). Plánujeme tiež analyzovat' nedatovanú ${ }^{14} \mathrm{C}$ vzorku a venovat' sa detailnejšiemu výskumu dreva monoxylu s ciel’om skúmat' jeho provenienciu. Napokon, digitálny 3D model by sme chceli využit' na podporu novej muzeálnej prezentácie šamorínskeho monoxylu, ktorú plánuje Žitnoostrovské múzeum v Dunajskej Strede.

\section{Pod'akovanie}

Za láskavé poskytnutie informácií o mieste a okolnostiach nálezu monoxylu d’akujeme pedagógovi a historikovi Lászlóovi Kovácsovi, autorovi pôvodnej správy o náleze člna (Kovács 1982). Za aktuálne informácie zistené v priebehu konzervovania d’akujeme reštaurátorovi Františkovi Šmigrovskému. Za informáciu o aktuálnom stave nálezového fondu z doby laténskej v oblasti Žitného ostrova d’akujeme kolegovi Radovi Čambalovi.

Túto prácu podporil Fond na podporu umenia a Agentúra na podporu výskumu a vývoja v rámci projektu APVV-14-0550. 


\section{Bibliografia}

Barta, P. 2008: Studies on Absolute Chronology of the Bronze Age in East-Central Europe: Methods and Applications. Vol. I, II. Dizertačná práca, Archeologický ústav SAV, Nitra.

Bronk Ramsey, C. 2009: Bayesian analysis of radiocarbon dates. Radiocarbon 51(1), 337-360.

Brezzinová, G. 2006: Sídliská a sídliskové nálezy z laténskej doby na juhozápadnom Slovensku. Študijné zvesti Archeologického ústavu Slovenskej Akadémie vied 40, 9-50.

Čaplovič, D. - Gašaj, D. - Olexa, L. 1978: Archeologické prieskumy na stavbách socializmu na východnom Slovensku. Archeologické výskumy a nálezy na Slovensku v roku 1977, 62-69.

Kovács, L. 1982: Cenný nález člna. Spravodaj múzea - Múzeumi Híradó 6, č. 3 (Žitnoostrovské múzeu/Csallóközi Múzeum, Dunajská Streda), 3-5.

Heiss, A. 2009: Anatomy of European and North American woods - an interactive identification key. Online source: http:/ / www.holzanatomie.at (navštívené 1. 3. 2016).

Lanting, J. N. 1998: Dates for origin and diffusion of the European logboat. Palaeohistoria 39/40, 627-650.

Martinelli, N. -Cherkinsky, A. 2009: Absolute dating of monoxylous boats from Norhern Italy. Radiocarbon 51(2), 413-421.

Passariello, I. - Marzaioli, F. - Lubritto, C. - Rubino, M. - D'Onofrio, A. - De Cesare, N. - Borriello, G. - Casa, G. - Palmieri, A. - Rogalla, D. - Sabbarese, C. - Terrasi, F. 2007: Radiocarbon sample preparation at the CIRCE AMS laboratory in Caserta, Italy. Radiocarbon 49(2), 225-232.

Pazdur, A. - Krapiec, M. - Michcryński, A. - Ossowski, W. 2001: Radiocarbon and dendrochronological dating of logboats from Poland. Radiocarbon 43(2A), 403-415.

Peška, J. 2000: Mohelnice (okr. Šumperk). Přehled výzkumů 44, 124-125.

Peška, J. 2020: Monoxyl a další dřevěné struktury v oblasti řeky Moravy z lokalit Moravičanských jezer na katastru Mohelnice. Přehled výzkumů 61, č. 1, 97-104.

Reimer, J. - Austin, W. E. N. - Bard, E. - Bayliss, A. - Blackwell, P. G. - Bronk Ramsey, C. - Butzin, M. - Cheng, H. Edwards, R. L. - Friedrich, M. - Grootes, P. M. - Guilderson, T. P. - Hajdas, I. - Heaton, T. J. - Hogg, A. G. - Hughen, K. A. - Kromer, B. - Manning, S. W. - Muscheler, R. - Palmer, J. G. - Pearson, Ch. - van der Plicht, J. - Reimer, R. W. - Richards. D. A. - Scott, E. M. - Southon, J. R. - Turney, C. S. M. - Wacker, L. - Adolphi, F. - Büntgen, U. - Capano, M. - Fahrni, S. M. - Fogtmann-Schuľ, A. - Friedrich, R. - Köbler, P. - Kudsk, S. - Miyake, F. - Olsen, J. - Reinig, F. Sakamoto, M. - Sookdeo, A. - Talamo, S. 2020: The Intcal20 Northern Hemisphere Radiocarbon Calibration Curve (0-55 kBP). Radiocarbon 62(4), 725-757.

Rogers, J. S. 2011: Czech Logboats: Early inland watercraft from Bohemia and Moravia. Sborník prací Filozofické fakulty Brněnské Univerzity M16, 171-202.

Schweingruber, F. H. 1990: Microscopic Wood Anatomy. Swiss Federal Institute for Forest, Snow and Landscape Research. Birmensdorf 1990. 
Terrasi, F. - De Cesare, N. - D'Onofrio, A. - Lubritto, C. - Marzaioli, F. - Passariello, I. -Rogalla, D. - Sabbarese, C. - Borriello, G. - Casa, G. - Palmieri, A. 2008: High precision 14C AMS at CIRCE. Nuclear Instruments and Methods in Physics Research B266, 2221-2224.

\section{Mapové podklady}

Geologická mapa Slovenska: http://apl.geology.sk/gm50js/ (navštívené 10. 11. 2020).

\section{Summary}

Article presents first results of an ongoing research and documentation project of one from two published archaeological logboats from Slovakia. The logboat was found during gravel extraction in Šamorín in 1982 (dist. Dunajská Streda, SW Slovakia). It survived in two large fragments of front and back part with the length of $332 \mathrm{~cm}$ and $187 \mathrm{~cm}$, respectively, width of the vessel is 59-65 cm. According to microscopic-anatomical determination, the boat was made from pine (Pinus sp.). Bayesian chronological modeling with two ${ }^{14} \mathrm{C}$ determinations on bulk wood and $\alpha$-cellulose has shown that the last retained tree-ring (not cambial ring) on the investigated part of the vessel grew in 350-265 cal BCE. Accordingly, we date the manufacture of logboat from Šamorín to the $3^{\text {rd }}$ century or later in the last third of the $1^{\text {st }}$ millennium cal BCE (La Tène periods LT B and LT C). Together with a $10.5 \mathrm{~m}$ long oak logboat from Mohelnice (Moravia, Czech Republic) they present direct evidence of morphometric variability in central European vessels of the Late Iron Age. 